\title{
The Use Local Characters Biography to Build Nationalism and Patriotism
}

\author{
Mus Rajilun \\ STKIP Kie Raha Ternate
}

\begin{abstract}
Nationalism (and patriotism as well) is one of the required characters which must be owned by individual or individual as a part of a society. Nowadays, there is an undeniable fact that our children, especially those in the junior and senior high schools, love more foreign characters (idols and heroes) rather than loving their national characters that fought for this land, Indonesia. There are many ways to teach history in order to build nationalism and patriotism characters of the students. One of the ways is by using biography. By involving 41 students of social science and 2 history teachers in a senior high school, this natural inquiry study shows that the biography of local character (local hero) can build the students' nationalism and patriotism with some noticeable challenges in the practice.
\end{abstract}

Keywords: biography, local character, local history, nationalism, patriotism

Correspondence. mus.rajilunmus@gmail.com

Article History. Received January 2019, Received in revised March 2019, Accepted June 2019

C2019. International Journal Pedagogy of Social Studies. Department of Social Studies Education

\section{A. INTRODUCTION}

Nationalism (and patriotism as well) is one of the required characters which must be owned by individual or individual as a part of a society. Nowadays, there is an undeniable fact that our children, especially those in the junior and senior high schools, love more foreign characters (idols and heroes) rather than loving their national characters that fought for this land, Indonesia. Most of our children are able to tell foreign histories more fluently rather than telling their national histories. Moreover, they are more fluent in singing foreign songs rather than their national songs (hymns). Perhaps, this is one of the globalization consequences brought in through media and technology. However, these daily facts - which need no further validation - indicate the lack of nationalism and simultaneously suggest us to take this issue into account.

Education is one of attempt which is responsible towards the quality of the students' nationalism and patriotism. Education is required to produce individual with strong nationalism and patriotism. If education cannot bring solution for this issue, national disintegration and multidimensional crisis are likely to happen (again) in the future (Anderson, 1999). Education cannot be seen in limited perspective - as a place where the students get knowledge - but should be seen as a chance for the students to build their characters. One of the education duties is to prepare the students (individuals) to play certain roles in society in the future (Karim, 1991).

The writer does not imply that the today education does not take this duty into account. However, the study on the history in the schools - perhaps - is focused more on the time and event rather than the values of the history itself (Winenburg, 2008). The teaching of history must have direct implication in the current time. The characters and the events in the past time must be reflected and become references for today action. The teaching of history in the school should not only raise the story of struggling in the past but also to bear in mind the emotional and moral values, sacrifice of the heroes, and what to do to appreciate all of those struggle. If this is not brought up in the history teaching, then the students may remember the story but the story does nothing on them. In line 
with this, Anderson (1999) states that if the youth (the students) know and can imagine how hard the struggle of the national characters in the past, they would appreciate the struggle and they would not waste them all. They will be aware that their country was not suddenly free but by fight and blood. Their love on their country will be leveled up and consequently their nationalism and patriotism are leveled up too.

If education practices pay attention on what the students can do today, then the teaching of history will produce more than then students who can remember names, events, years, and worn things. The students will have strong nationalism and patriotism. This is, of course, a long term education practice that will have positive impact in the social and national life.

There are many ways to teach history in order to build nationalism and patriotism characters of the students. One of the ways is by using biography. This study was done to investigate how the implementation of biography based model can build nationalism and patriotism characters of the students and the potential difficulties that teacher can deal in implementing this model.

\section{B. Theoretical Review}

\section{Nationalism and Patriotism}

In order to successfully encourage the students to have the spirit of nationalism and patriotism through the teaching of history, the distinction between nationalism and patriotism is important to be made. Some teachers in the school might find it difficult to describe the difference between these two terms because those are commonly used interchangeably. For the sake of measurement, these two terms must be distinguished therefore teacher can measure his or her teaching achievement.
Etymologically, the term nationalism is a derivation from the word nation which is rooted from Latin word natio. This word has a long story from ancient Rome to Latin. People in ancient Rome use the word "natio" with negative meaning because this word was used to refer to people, race, or ethnic which was identified as "barbarians" according to Rome moral ruler. This word then was adopted by Latin sub-languages such as French, Italian, and English which gave it meaning "mother land." Today, the word nation is broadly defined as a collection of people who have shared identities including history and language (Wijayanto, 2008).

Cultural unity and political sovereignty are two important keywords to understand the meaning of nationalism generally. Cultural unity is the unity built on the shared properties of the cultures. However, this keyword is not applicable in Indonesia since Indonesia is rich of different cultures although cultural differences in Indonesia can be framed into one flag (Bhineka Tunggal Ika). It does not imply that nationalism in this keyword has no meaning in Indonesia. Javanese can have strong nationalism based on their local culture and history, Sundanese can have scrong nationalism based on their local culture and history, and so forth. Political sovereignty is the sense of freedom or independent as a nation.

By having the sense of belonging towards the culture (by cultural nationalism) and country (political nationalism), a nation can determine their actions independently to attain national goals. This also entails the doctrine that our national culture and interests are superior to any other. This eventually grows the love of country and willingness to sacrifice for it which we call patriotism. 
Patriotism is the attitude of love and willingness to sacrifice for the sake of the nation or country. Patriotism is synonymous to heroism; hero is the character who fights for a nation or a country. The fight, struggle, and sacrifice can involve means and even life (Cohen \& Nussbaum, 1996).

Patriotism has different dimension and terms but Staub \& Schwartz (1994) figured out two important distinctions of patriotism which are called blind patriotism and constructive patriotism.

Patriotism, according to Staub \& Schwartz (1994) is a kind of attachment towards the group or sense of belonging. This group is not only in kind of country but also political party, religion, social class, and so on. Patriotism becomes an attribute which an individual or members of a group identify themselves and at the same time becomes the power which emerges loyalty towards the group.

Constructive and blind patriotism differ on the ground. Some people are loyal to the country because they know or they have nationalism value as their characters. Some other people are loyal without questioning and without understanding toward the reasons. These people are closed-minded and are not open toward criticisms. These two types of people are examples of patriotism; the former is constructive patriotism and the latter is blind patriotism.

If our children are about to be taught patriotism, of course it is constructive patriotism. Our children must have the spirit of nationalism and constructive patriotism. Constructive patriotism encourages us to accept or to appreciate criticisms and this character supports our development to be better in the future. Blind patriotism is not a choice because it has unexpected consequences which not only disturb the harmony between the group but also disturb the harmony within the group.

\section{The Teaching of History in the School to Build Nationalism and Patriotism}

There is a misconception among the social science teachers about history as a subject. Some teachers perceive history as an event in the past time and therefore to measure their success in teaching history they test the students' memory about names, places, events, and artifacts. Eventually, this perception will lead the students to nothing more than nostalgic knowledge. The students do not have expected characters from the learning process.

History (as subject or as science) is a science which studies the process of development and continuation in temporal dimension. Based on this perspective, the teaching of history in the school must be grounded on purposes such as to build shared memory, temporal perspective understanding, and awareness on the national core values. In the other words, history is a subject which grows knowledge and values about society development from past to current time and to see the possibility in the future.

There are many purposes to be achieved from teaching history to the students. Through history, the students can develop their chronological thinking competence to describe the process of social development and the cultural variety on behalf to grow the national identity in the middle of global life. Teaching history is also important to make the students aware on the different cultures (within the country), perspectives, religions, and to appreciate these differences to maintain social harmony. The students' critical and analytical thinking competence are also supported by learning history which is very crucial to see the past experiences and to connect that experiences to the current time and to see the possibility in the future. From this perspective, 
nationalism and patriotism are two values to be taught through history.

Through the teaching of history, the students understand the struggle in the past time and what to do in the current time as the appreciation of the struggle. The values of the struggle can build the love on the country (nationalism) and also can build the sense of belonging and the will to develop and sacrifice for the country in the current time and in the future (patriotism). This can be achieved if both the teachers and the students understand that history is not only about the events in the past.

National or social disintegration is a challenge for all history teachers. The challenge is to increase the national and social integration. When the students do not have a role model (national characters in this case) to "imitate", they will experience multidimensional crisis and this is the challenge that teachers of history take. Here biography of the national character makes sense. The students do not only learn the story from the biography but also to extract the core values (nationalism and patriotism) from the biography.

\section{Biography and Historical Values}

Biography can be a reasonable choice because it contains the historical values including nationalism and patriotism. Every history teacher uses biography of national characters (heroes of struggle) in teaching history, but some of them use biography as the source of the story, not as the source of historical values. In order to successfully implement biography model, it is crucial to understand the meaning of the historical value itself.

Value, etymologically, is a derivation of Latin word valere. This word has been terminologically understood as general belief about desirable or understandable goals or endstates (Mulyana, 2004). In common sense, value is the ideal accepted by some individual or group. When value is strongly grounded through social history, it becomes a belief system. As a belief system, value rules how people interact and how people behave to achieve shared goals or shared end-state.

How values are initiated is important to notice. According to Schwartz et al (1999), values are initiated based on the following needs: (a) individual needs as a biological organism, (b) social interaction requirement that needs interpersonal coordination, and (c) demand of social institution to achieve social prosperity and social life continuation.

Based on the mentioned needs above, it can be said that values come from universal human need reflected through organismic needs, social motives, and social institution demand. In this perspective, value becomes a required need since human is a biological and social creature that lives and interact within a society. Values, eventually, not only become grounded beliefs but also social guidance in human life (Muthohar, 2009).

Historical value, then, can be understood as ideal or belief system which is built based on the understanding of history. Values, in this case, must be distinguished from knowledge. By learning history, students may have a set of knowledge about the history itself. However, it does not mean that the students may grow the values from the history. In order to grasp the value from the historical material, the students need a teacher who can interpret the history and extract the ideas which can be taken as a belief and a guide in current life.

If the teacher expects the students to have the values from the history, he 
must be able to not only delivering the cognitive aspect of the history but also the affective aspect as well. Cognitive aspect is related to memory and affective aspect is related to emotion. Emotional aspect of the history must be interpreted and delivered in some ways so that the students can grasp the values of the history. For example, when students read a historical text without affection, the students may have memorized the events but they do not take any value from the text. This happens because the students are not qualified enough to see the importance of history until the teacher brings it up.

The example above indicates that there is at least a historical text which is a rich source of historical information. Since there are many types of historical text, teacher can choose one of them. According to the writer, a biography (or autobiography) of a national character (national hero) is a good choice and the reason will follow.

Generally, biography is defined as an account of the series of events making up a person's life. In other words, biography is a text which contains series of events which making up a person's life. If the person is a national hero, then the series of events are the struggles of the hero. For example, in this study the writer used biography of Babullah (a sultan of Ternate). The biography of Babullah contains the stories of his struggles against colonialism in Ternate.

Through this biography, the teacher does not only tell the story or the series of events but also to rise up the values of his struggle to defend the colonialist to achieve the freedom. The characters lived under pressures, hunted, wounded, but they had love for this country and they fought for it. The text is rich of psychological effects that can be utilized to grow the sense of belonging and those are the important historical values to be taken into account.

Nationalism and patriotism are values which can be grasped from the historical text such as a biography. Of course, there are types of values that need to be considered. If the value from the biography is not delivered appropriately and without careful explanation - the students can be leaded to blind patriotism. Therefore, it is the teacher that plays important role in teaching history by using biography to deliver the material and to explain the values needed by the students to learn.

In short, the biography presents the characters of the hero that can be modeled by the students in logical and affective way. However, it is not the only one importance of a biography of a national hero. The way they love the country and the reason in doing so are the historical values which will guide the students or our children to behave in the current time.

\section{METHOD}

This research was designed as naturalistic inquiry under qualitative method. As this research attempted to see how biography supports the building of nationalism and patriotism, it was considered as inquiry. The data was texts and therefore it matched qualitative method (Creswell, 1998). The researcher also did not attempt to manipulate the research setting and therefore naturalistic inquiry was decided to be taken as the design.

This research involved 41 students of a senior high school (Senior High School 3 of Ternate). They were purposively selected based on their major, social science. Furthermore, 2 teachers of history were also involved as the informant.

The data were collected through observation, documentation, and interview. The researcher observed the 
classroom interaction especially in the history teaching and learning process. The researcher also distributed questionnaire to the students. This questionnaire was used to see the level of understanding on the materials and their nationalism and patriotism before and after the use of biography in learning history. Teachers were interviewed to attain relevant information regarding the history teaching and learning process.

Those data were discussed and interpreted descriptively. The research organized, reduced, and interpreted the data by synthesizing the data and the related theories. Then, from this analysis the researcher took conclusion.

\section{RESULT AND DISCUSSION}

\section{The use of local character biography in teaching history}

In the history classroom practice, the students are introduced with two scopes of history: national history and local history. This study focused on the local history where the biography of Babullah is used as the source of material. Despite, material concerning national history is also integrated within the lesson. This was done by the teachers to enrich the material and also to reflect the historic-cultural pluralism in Indonesia.

The teachers were handed a biography of Babullah which contains not only the struggle stories but also private life of him. They were required to deliver the information from the text to the students in order to enhance the students' nationalism and patriotism spirit. The researcher observed the classroom processes and some information from the field notes (observation) and interview can be discussed as follows.

The researcher observed that the students were confused when they were introduced to local character (Babullah). Although they knew the character, they never read it from various historical texts because Babullah was never mentioned as one of the national heroes.

In delivering this material, the teacher started by explaining national history and then related it to local history. The deepening process was done by discussing and asking questions toward the students about the difference of character in national and local struggle to fight colonialists. However, the teacher seemed to not master how to integrate national and local history to raise the spirit of nationalism and patriotism of the students. The teaching objectives should not be limited to the students' memorization (cognitive aspect) but also the emotional effect (affective aspect) where the students do not only remember names and events but also appreciate the struggle.

Based on the teaching document, the researcher found that the teaching material provided or prepared was focused on the national history, decree of colonialist in Indonesia in the century of $19^{\text {th }}-20^{\text {th }}$. After having the local history materials, the document was revised by adding local history; the fighting of Ternatese against Portuguese in 15701583 under Babullah's command. The teacher was not ready enough to integrate this local history because they were habituated to use textbooks which contain only national characters or heroes whereas Babullah was not one of them. In order to overcome this problem, according to a teacher, she must go to local library to find the source text for local history. Moreover, she interviewed some local historians to gather more information about local heroes. From the information gathered, the teacher then reintegrated the material (national and local histories) by having a red thread that national struggle was impossible to attain a goal without local struggle. In the other 
words, it was the local heroes and their struggle that made the leaving of colonialists.

The other influencing aspect in the teaching of local history in the classroom was the curriculum. The use of school based curriculum has helped the school very much to integrate the local history into the lesson. Before this curriculum, as a teacher said, the focus of the lesson has been determined by the government and consequently many of local histories were not included. This had leaded to consequences that not only do the students but also the teachers not knowing much about local history especially students and teachers who came from other provinces. The implementation of school based curriculum had given chances to the school to enrich their history material with local history without abandoning the national history.

Measuring affections including nationalism and patriotism is not as easy as measuring students' memory and understanding on the history material. The teacher confessed that they were tailored to use written tests and most of the tests were about names, places, events, and times. By having discussions with the researcher, the teachers were informed to consider measuring the students' critical and analytical thinking (e.g. reasoning and problem solving).

The teachers latter designed the test by including analytical questions which not only refer to the past events told in the story but also the implementation of it in the current time. In a session, the teacher asked to the students why Babullah commanded the citizenry of Ternate to fight the colonialist. The students gave various answers. Some of them answered that Babullah commanded the citizenry to fight because they must defend their land. One of them answered that it happened because Babullah was very sad and angry because his father (Khairun) was assassinated by the colonialist. More about the students' responses will be discussed in the next part.

Based on the discussion above, the process of using biography of local character in teaching history is challenging. The challenges and the opportunities can be described trough the following table:

Table 1. Challenges and Opportunities in implementing biography of local character in teaching history.

\begin{tabular}{|c|c|}
\hline Challenges & Opportunities \\
\hline $\begin{array}{l}\text { The students' do not have rich knowledge } \\
\text { about local heroes because some of them are } \\
\text { not noted in the textbooks as national heroes } \\
\text { including Babullah. }\end{array}$ & $\begin{array}{l}\text { Texts concerning local history and local } \\
\text { characters must be provided by the school } \\
\text { in order to fulfill the teachers and the } \\
\text { students need in learning history. }\end{array}$ \\
\hline $\begin{array}{l}\text { The teachers are more familiar with national } \\
\text { history therefore to integrate local history in } \\
\text { the lesson they deal with difficulties. }\end{array}$ & $\begin{array}{l}\text { Looking for texts in the library and } \\
\text { interviewing the local historians can fulfill } \\
\text { teachers' need and to solve the problem. }\end{array}$ \\
\hline $\begin{array}{l}\text { Not all curriculum involved local history as the } \\
\text { material to deliver in the history classroom. }\end{array}$ & $\begin{array}{l}\text { Implementing school based curriculum. } \\
\text { The tests were revised to include critical }\end{array}$ \\
\hline $\begin{array}{l}\text { The tests were designed more to measure } \\
\text { students' cognitive aspect rather than affective } \\
\text { aspect. }\end{array}$ & $\begin{array}{l}\text { and analytical thinking including } \\
\text { reasoning and problem solving in the } \\
\text { current time. }\end{array}$ \\
\hline
\end{tabular}


From the table above, it can be seen that the teachers needed help from many sources including local historians for a teaching history with local character biography to be success. It does not imply that the teachers were not skillful enough to stand in the front of the classroom but they were tailored to deliver national history and focused on the students' memorization on the history.

Since nationalism and patriotism are affective aspect in the learning process, the teachers must be able to shift from one teaching paradigm to another. The teachers are not only required to deliver material but also required to increase the students' psychological connection to the history. This can be done by raising the mental aspect of the character when they were in the struggle and their private life.

The students' critical and analytical thinking should be increased by relating the past events told by the story and the current time. As the teachers in this research tried to do, the students successfully abstracted or imagined that the freedom of this land was achieved by local fighters and heroes and that must be maintained. This was projected through the students' responses towards the teachers' questions (observation) and the researcher's questions (interview) which will be discussed in the following part.

\section{The students' nationalism and patriotism}

There is a difference between conventional teaching model of history and using biography in teaching history. In conventional model, students' learning is focused more on the events whereas in using biography the students' learning is focused more on the person. In the use of biography, the students' awareness shifts from general (people who struggle) to particular person. In this change, the students can take benefit by seeing the person as the model to impersonate. Moreover, although conventional teaching of history includes persons, but it is not as detailed as biography can over. Since nationalism and patriotism are values to be grounded to the students' hearts, they need a model and biography can provide such information to fulfill this requirement.

In this study, the researcher observed that the students enjoyed the classroom very much although some confusion appeared because they usually discussed national characters and not local characters. They also confessed that they rarely heard story about Babullah (the person in discussion). Although they knew who he was, but they did not have much information about him. Nevertheless, this seemed to increase their curiosity and eventually mental connection between them and the person was constructed. One of the students, in interview, said:

"This time we learn differently. I found that studying history through Sultan Babullah's story is so joyful because it is directly related to the place where we live."

Another student said:

"Usually, we discuss the heroes in Java or Makassar like Diponegoro or Imam Bonjol. But today we discuss about Sultan Khairun and Sultan Babullah. I really like to follow that class. I just know if Babullah was a brave man and he loved this land very much."

When this is confirmed to the teachers in a session in interview, the teacher said: "In order to teach local history, I must start the class with national history. The students need to understand the values of democracy and multiculturalism 
of Indonesia. This is important for they must appreciate the history and culture that other provinces have."

Based on the brief responses from the students and teacher above, it can be said that the use of local character biography in teaching history is preferable in the classroom. However, it does not mean that national history is less important. The discussion should integrate both national and local history. In a classroom session, after delivering the material, the teacher gave some questions to the students. The questions are about what they feel when they heard the story and what they think about some people who love foreign character than their national or local character. Here are some responses noted by the researcher (similar responses are not displayed but merged):

- Babullah was a brave man. He was sad because his father was assassinated in an invitation by colonialist. I feel so sad to hear the story.

- I think we need more people like Babullah today. Ternate could be better if it is governed by people like this.

- I don't know. If Babullah did not have that kind of heart, I don't know what would happen with us today.

- Perhaps, people who love foreign characters or heroes more than local heroes do not know their local history. If they know, I think they will consider that foreign characters or heroes are number second.

- I want to visit Babullah's grave.

- People are free to choose the heroes they like. But most of people now are irrational. Babullah is a real character but they choose to take fictional characters as their hero.

The students' responses above show their affection towards Babullah. Some of the students did not answer the questions, perhaps they did not understand what was being asked. It can be seen that some responses reflect the critical thinking of the students. It is also seen that they tried to imagine the existence of Babullah's personality (as model) in the current time.

In individual interview, the researcher asked about the students' sense of belonging towards their own local history and culture. Some noted responses are:

"I will do everything that I can to maintain my local history. I want to know more about our local history and local culture. I want to write it in my blog."

Another student responded:

"My father is not from here (Ternate). My mother is. However, my mother never told me story like this. I don't know much about Ternate history but I make sure that I will find it out."

Beside these responses, there are many similar responses that the researcher does not present. However, from the average responses, it seemed like biography of local character can construct the students' nationalism and patriotism. Although some students were not from Ternate, they were interested toward the local history and the story of the local character.

The responses that the researcher gathered from the field indicated that the students value the local history and local character (Babullah in this case) very much. They started to be aware of the importance of local history and local character. Using biography of local character had successfully made the local history and local character valuable. This 
value can be the base of nationalism and patriotism development.

However, if the teachers are not able to raise the value of the story, then it is difficult for the students to value the story. Therefore, the teachers' skill in delivering material and raising the values from the story are imperative.

From this reduced discussion, it can be assumed that the use of biography in teaching local history to develop students' nationalism and patriotism rely on the teachers' ability to deliver the material in the classroom. Data from the students' responses reveal that they were interested towards local history and local character and by that their nationalism and patriotism increased. However, due to the lack of provided text concerning local character and the history, the teachers must be able to collaborate with the local historians to enrich the historical information.

\section{E. CONCLUSION}

The history itself cannot build nationalism and patriotism of individual. It is the values from the history that play the role. The use of biography is one of the choices to build nationalism and patriotism. The biography of local character is a valuable material source in teaching history especially to develop or to build the students' nationalism and patriotism.

Some noticeable problems may appear in implementing the biography of local character in teaching history including the lack of knowledge and source text, the difficulty to integrate local and national history, and the measurement or the evaluation system. Since history is not only about names, places, and events but also values, the evaluation must be designed not only to measure the cognitive aspect but also the affective aspect.
Lastly, the use of biography has successfully built the students' nationalism and patriotism since they become more aware on the importance of the struggle values to defend their land. Simply, the person in biography has become the model that grows the students' sense of belonging.

\section{REFERENCES}

Anderson, B. (1999). KomunitasKomunitas Imajiner: Renungan tentang Asal-Usul dan Penyebaran Nasionalisme. Yogyakarta: Pustaka Pelajar.

Cohen, J. \& Nussbaum, M. C. (1996). For Love of Country: Debating the Limits of Patriotism. Beacon Press.

Creswell, J. W. (1998). Qualitative Inquiry and Research Designs: Choosing among Five Traditions. London: Sage Publication, Inc.

Karim, R. (1991). Pendidikan Islam di Indonesia: Antara Cita dan Fakta. Yogyakarta: Tiara Wacana.

Mulyana, R. (2004). Mengartikulasikan Pendidikan Nilai. Bandung: Alfabeta.

Muthohar, S. (2009). Upaya Menanamkan Nilai-Nilai Perjuangan Pahlawan. Makalah pada Sarasehan Pemerintah Blora, 25 Mei 2009.

Staub, E. \& Schwartz, R. T. (1994). Manifestations of blind and constructive patriotism: personality correlates and individual-group relations. Chicago: Nelson-Hall Publisher.

Wijayanto, H. (2008). Memahami Nasionalisme. Online article accessible in: http://jeremiasjena.wordpress.com.

Winenburg, S. (2008). Berpikir Historis: Memetakan Masa Depan, Mengajarkan Masa Lalu. Jakarta: Buku Obor. 